\title{
FAKTOR-FAKTOR YANG MEMPENGARUHI MINAT MAHASISWA AKUNTANSI DALAM PEMILIHAN KARIR SEBAGAI AKUNTAN PUBLIK
}

\author{
Fenti Febriyanti \\ fenti19@yahoo.com \\ Universitas Serang Raya
}

\begin{abstract}
ABSTRAK
Penelitian ini bertujuan untuk meguji secara empiris Pengaruh Penghargaan Finansial terhadap minat mahasiswa akuntansi dalam pemilihan karir sebagai akuntan public, Pengaruh Pertimbangan Pasar Kerja terhadap minat mahasiswa akuntansi dalam pemilihan karir sebagai akuntan public, Pengaruh Lingkungan Keluarga terhadap minat mahasiswa akuntansi dalam pemilihan karir sebagai akuntan public, Pengaruh Personalitas terhadap minat mahasiswa akuntansi dalam pemilihan karir sebagai akuntan public, Pengaruh Pengakuan Professional terhadap minat mahasiswa akuntansi dalam pemilihan karir sebagai akuntan public, Pengaruh Lingkungan Kerja terhadap minat mahasiswa akuntansi dalam pemilihan karir sebagai akuntan public. Penelitian ini termasuk kedalam jenis penelitian kuantitatif dengan metode purposive sampling. Sampel penelitian ini sebanyak 129 mahasiswa S1 Akuntansi Universitas Serang Raya. Instrument penelitian ini berupa kuesioner dengan menggunakan skala likert. Metode analisis data dilakukan dengan menggunakan bantuan program spss (Statisticial Package For social Science). Alat analisis yang digunakan dalam penelitian ini yaitu analisis regensi berganda. Hasil penelitian diperoleh bahwa Penghargaan Finansial, Pertimbangan Pasar Kerja, Lingkungan Keluarga, Personalitas, Pengakuan Profesional dan Lingkungan Kerja berpengaruh signifikan terhadap Minat mahasiswa dalam pemilihan karir sebagai akuntan public.
\end{abstract}

Kata kunci- Penghargaan Finansial, Pertimbangan Pasar Kerja, Lingkungan Keluarga, Personalitas, Pengakuan Profesional, Lingkungan Kerja.

\section{ABSTRACT}

This study aims to empirically examine the effect of financial awards on the interest of accounting students in career selection as a public accountant, the influence of labor market considerations on the interests of accounting students in career selection as a public accountant, family environment influence on the interest of accounting students in career selection as a public accountant The influence of personality on the interest of accounting students in career selection as a public accountant, the effect of professional recognition on the interest of accounting students in career selection as a public accountant, the influence of the work environment on the interest of accounting students in career selection as a public accountant. This research belongs to the type of quantitative research with a purposive sampling method. The sample of this study was 129 S1 Accounting students at Serang Raya University. The instrument of this research is a questionnaire using a Likert scale. The method of data analysis is done using the help of the SPSS (Statistical Package For Social Science) program. The analytical tool used in this study is multiple regency analysis. The results showed that Financial Awards, Labor Market Considerations, Family Environment, Personality, Professional 
Recognition, and Work Environment had a significant effect on student interest in career selection as a public accountant.

Keywords - Financial Awards, Labor Market Considerations, Family Environment, Personality, Professional Recognition, Work Environment.

\section{PENDAHULUAN}

Undang-undang Nomor 5 Tahun 2011 tentang akuntan public menjelaskan bahwa yang dimaksud dengan akuntan public adalah suatu profesi yang jasa utamanya adalah jasa asurans dan hasil pekerjaannya digunakan secara luas oleh public sebagai salah satu pertimbangan penting dalam pengambilan kepurtusan. Akuntan public memiliki peranan yang sangat besar dalam mendukung perekonomian nasional yang sehat dan efesien serta meningkatkan transparansi dan mutu informasi dalam bidang keuangan (Harianti, 2017) . Menurut Pusat Pembinaan Akuntan Jasa dan Penilai (PPAJP) pertumbuhan akuntan public di Indonesia masih rendah yaitu $4 \%$ pertahun. Berikut dapat dilihat jumlah perkembangan akuntan public di Indonesia.

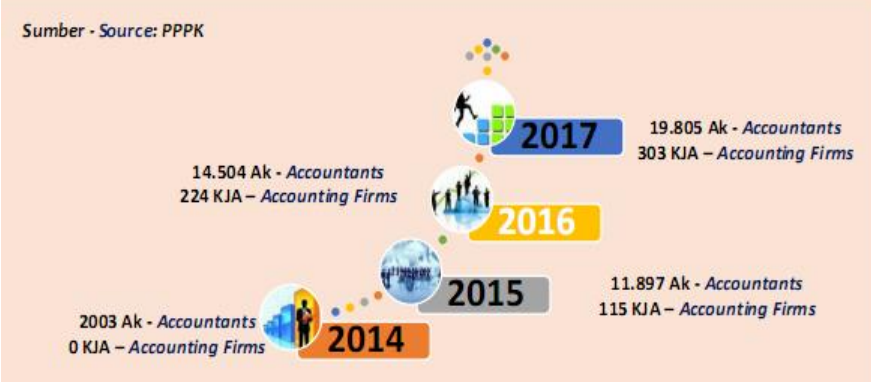

Gambar 1, Perkembangan jumlah akuntan dan Kantor Jasa Akuntan (KJA) di Indonesia Tahun 2014-2017

Fenomena ini mengindikasikan kurangnya minat mahasiswa akuntansi untuk menjadi akuntan public. Minat mahasiswa akuntansi untuk menjadi akuntan public merupakan suatu keinginan. hasrat ataupun kehendak mahasiswa untuk berprofesi sebagai akuntan public (Harianti, 2017).

Minat pada dasarnya adalah penerimaan akan suatu hubungan antara diri sendiri dengan diluar diri (Fitria, 2016). Socioeconomic Theory mengatakan kondisi social seperti orang tua, teman, guru, status social dan status ekonomi seperti peluang pekerjaan/pertimbangan pasar kerja, jumlah gaji dan sejenisnya menjadi pertimbangan pada pemilihan karir mahasiswa (Venabele, 2015).

Penelitian yang relevan mengenai factor yang mempengaruhi minat mahasiswa akuntansi dalam pemilihan karir sebagai akuntan public telah banyak dilakukan tetapi hasil penelitiannya masih berbeda-beda. Apriliyan dan Laksito (2011) menyatakan bahwa secara simultan dan parsial variable penghargaan finansial, pertimbangan pasar kerja, pengakuan professional, pelatihan professional, nilai-nilai social, dan personalitas berpengaruh signifikan terhadap pemilihan karir menjadi akuntan public sedangkang lingkungan kerja tidak berpengaruh signifikan terhadap pemilihan karir menjadi akuntan public. Penelitian yang dilakukan oleh Suyono (2014) meneliti mengenai analisis factor-faktor yang mempengaruhi pemilihan karir sebagai akuntan public. Hasil penelitian menunjukan bahwa secara parsial factor 
penghargafinansial, pelatihan professional, nilai-nilai social, pertimbangan pasar kerja dan personalitas memiliki pengaruh terhadap pemilihan karir sebagai akuntan public sedangkan factor pengakuan professional dan lingkungan kerja tidak berpengaruh signifikan terhadap pemilihan karir sebagai akuntan publik.

Fifi (2014) meneliti mengenai Analisasi factor-faktor yang mempengaruhi minat mahasiswa akuntansi untuk berkarir sebagai akuntan public. Hasil analisis menunjukan bahwa secara bersamaan nilai intristik, pertimbangan pasar kerja, dan lingkungan kerja tidak berpengaruh terhadap minat mahasiswa akuntansi untuk menjadi akuntan public sedangkan penghasilan berpengaruh signifikan terhadap minat mahasiswa akuntansi untuk menjadi akuntan public.

Berdasarkan penelitian-penelitian terdahulu masih menunjukan hasil yang berbeda-beda. Hal ini diduga karena perbedaan variable independen yang digunakan berbeda-beda. Berdasarkan hal tersebut membuat peneliti tertarik untuk melakukan penelitian kembali agar mendapatkan hasil yang lebih baik.

\section{TINJAUAN PUSTAKA DAN PENGEMBANGAN HIPOTESIS}

\section{A. Pengaruh Penghargaan Finansial Terhadap Minat Mahasiswa Dalam Pemilihan Karir Sebagai Auditor}

Penghargaan finansial merupakan kontraprestasi dari pekerjaan yang telah diyakini secara mendasar bagi sebagian besar perusahaan sebagai daya tarik utama untuk memberikan kepuasan kepada karyawannya. (Harianti, 2012). Dengan gaji dan upah, karyawan akan dapat memenuhi kebutuhan fisik, status social dan egoistiknya sehingga memperoleh kepuasan kerja dari jabatannya (Rivai, 2013).

Alhdar (2013) meneliti secara simultan bahwa penghargaan finansial memiliki pengaruh signifikan terhadap pemilihan karir sebgai akuntan publik oleh mahasiswa akuntansi dan PPAK di Universitas Hasanudin. Sedangkan menurut Merdekawati dan sulistiawati (2011) penghargaan finansial tidak berpengaruh terhadap pemilihan karir sebagai akuntan public dan non akuntan public terhadap mahasiswa perguruan tinggi swasta dikota Medan. Berbeda dengan Aprilyan dan Laksito (2011) yang menyatakan bahwa penghargaan finansial secara simultan dan parsial berpengaruh signifikan terhadap pemilihan karir menjadi akuntan public.

Berdasarkan uraian diatas dirumuskan hipotesis sebagai berikut :

H1: Penghargaan finansial berpengaruh terhadap minat mahasiswa dalam pemilihan karir sebagai akuntan publik.

\section{B. Pertimbangan Pasar Kerja terhada Minat Mahasiswa dalam Pemilihan Karir sebagai Auditor}

Pasar kerja adalah suatu keadaan dimana ada atau tersedianya pekerjaan yang dapat dimasuki oleh individu-individu sesuai dengan keahliannya masing-masing (Nuraini, 2008). Menurut Suyono (2014) pekerjaan yang memiliki pasar kerja yang lebih luas akan lebih diminati dari pada pekerjaan yang pasar kerjanya kecil.

Hasil Penelitian yang dilakukan Putro (2011) dan Mega (2011) menyatakan bahwa pertimbangan pasar kerja secara signifikan berpengaruh terhadap minat mahasiswa auntansi dalam berkarir sebagai auntan publik.berbeda dengan penelitian yang dilakukan oleh Merdekawati dan sulistyawati (2011) yang mengatakan bahwa factor pertimbangan pasar kerja tidak berpengaruhterhadap pemilihan karir akuntan public dan non akuntan public terhadap mahasiswa perguruan tinggi swasta dikota Medan. Berdasarkan uraian diatas, maka dirumuskan hipotesis sebagai berikut : 
$\mathrm{H} 2$ : Pertimbangan pasar kerja berpengaruh terhadap minat mahasiswa dalam pemilihan karir sebagai akuntan publik

\section{Pengaruh Lingkungan Keluarga terhadap Minat Mahasiswa dalam Pemilihan Karir sebagai Auditor}

Secara psikologis, lingkungan mencakup segenap stimulus yang diterima oleh individu mulai sejak dalam konsesi, kelahiran sampai matinya. Stimulasi itu dapat berupa sifat, interaksi, selera, keinginan, perasaan, tujuan-tujuan, minat, kebutuhan, kemauan, emosi, dan kapasitas intelektual (Dalyono, 2005). Menurut Santoso, 2014, lingkungan keluarga merupakan lingkungan pertama yang mula-mula memberikan pengaruh yang mendalam bagi anak. Minat mahasiswa akuntansi untuk menjadi seorang akuntan publik tidak hanya dipengaruhi oleh faktor instrinsik, tetapi juga dipengaruhi faktor ekstrinsik, seperti lingkungan keluarga (Widayanti dan saputra, 2018). Penelitian Santoso (2014) menemukan lingkungan keluarga memiliki pengaruh signifikan positif terhadap minat menjadi akuntan publik pada mahasiswa akuntansi. Sementara itu Chan (2012) meneliti mengenai analisis factor-faktor yang mempengaruhi pemilihan karir menjadi akuntan publik oleh mahasiswa jurusan akuntansi, hasil menunjukkan pelatihan profesional dan personalitas berpengaruh signifikan terhadap minat menjadi akuntan publik. Sedangkan variabel penghargaan finansial, lingkungan kerja, pertimbangan pasar kerja dan pencapaian akademik tidak berpengaruh signifikan terhadap minat menjadi akuntan publik. Selanjutnya Widayanti dan Saputra (2018) meneliti pengaruh penghargaan finansial, pertimbangan pasar kerja dan lingkungan keluarga terhadap minat menjadi akuntan publik, hasil penelitian menunjukan bahwa penghargaan finansial, pertimbangan pasar kerja dan lingkungan keluarga mempunyai pengaruh yang positif terhadap minat menjadi akuntan publik. Berdasarkan paparan yang dikemukakan diatas maka hipotesis yang diajukan sebagai berikut:

H3: Lingkungan keluarga berpengruh terhadap minat mahasiswa dalam pemilihan karir sebagai akuntan publik.

\section{Pengaruh Personalitas terhadap Minat Mahasiswa dalam Pemilihan Karir sebagai Auditor}

Menurut Rahayu (2003) personalitas merupakan salah satu determinan yang potensial terhadap prilaku individu saat berhadapan dengan situasi/kondisi tertentu. Sedangkan menurut Wicaksono (2011) mahasiswa yang memilih karir sebagai akuntan publik, akuntan pendidik, akuntan perusahaan dan akuntan pemerintah menanggap karir yang dipilihnya tidak mencerminkan kepribadian yang dimilikinya. Hasil penelitian yang dilakukan oleh Chan (2012) dimana personalitas berpengaruh signifikan terhadap minat mahasiswa akuntansi berkarir sebagai akuntan publik. Hal ini sejalan dengan penelitian yang dilakukan oleh Dianati (2017) personalitas semakin sesuai dengan kepribadian seseorang dengan pekerjaan menjadi akuntan publik maka minat mahasiswa dalam pemilihan karir sebagai akuntan public menjadi tinggi.

Berdasarkan penjelasan diatas, dirumuskan sebuah hipotesis yaitu :

H4 : Personalitas berpengaruh terhadap minat mahasiswa dalam pemilihan karir sebagai akuntan publik.

\section{E. Pengaruh Pengakuan Profesional terhadap Minat Mahasiswa dalam Pemilihan Karir sebagai Auditor}

Pengakuan professional adalah harapan seseorang ketika seseorang menjadi akuntan publik ia berharap mendapatkan pengakuan prestasi. Seseorang yang melakuakn prestasi tersebut akan mempunyai semangat agar dapat meningkatkan kinerja mereka (Dianati, 2015). Pengakuan professional mencakup sesuatu yang berhubungan dengan pengakuan terhadap prestasi dan keberhasilan dari suatu pekerjaan. Dengan diakuinya prestasi kerja akan dapat meningkatkan 
kualitas pekerjaan yang dihasilkan dan dapat meningkatkan motivasi dalam pencapaian karir yang lebih baik (Sartika, 2014). Penelitian yang dilakukan Merdekawati dan Sulistyawati (2011) sejalan dengan penelitian yang dilakukan oleh Apriliyan dan Laksito (2011) bahwa factor pengakuan professional berpengaruh signifikan terhadap pemilihan karir menjadi akuntan publik. Dari uraian diatas, dirumuskan penelitian sebagai berikut :

H5 : Pengakuan professional berpengaruh terhadap minat mahasiswa dalam pemilihan karir sebagai akuntan publik.

\section{F. Pengaruh Lingkungan Kerja terhadap Minat Mahasiswa dalam Pemilihan Karir sebagai Auditor}

Lingkungan kerja adalah segala sesuatu yang ada disekitar para pekerja dan dapat mempengaruhi dirinya dalam menjalankan tugas-tugas yang dibebankan (Nuraini, 2013). Karakter yang keras dan komit dibutuhkan oleh seseorang akuntan dalam menghadapi lingkungan pekerjaan (Sartika, 2014). Deadline waktu yang diberikan untuk menyelesaikan suatu pekerjaan mendorong akuntan untuk dapat menguasai lingkungan kerjanya agar nyaman dan tenang dalam bekerja (Andersen, 2011). Penelitian yang dilakukan oleh Merdekawati dan Sulistyawati (2011) menyatakan bahwa factor lingkungan kerja tidak berpengaruh terhadap pemilihan karir akuntan public dan non akuntan publik terhadap mahasiswa perguruan tinggi swasta dikota Medan. Berbeda dengan penelitian yang dilakukan oleh Alhadar (2013) menyatakan bahwa secara simultan factor lingkungan kerja memiliki pengaruh signifikan terhadap pemilihan karir sebagai akuntan public. Sejalan dengan penelitian yang dilakukan oleh Aprilyan dan Laksito (2011) yang meyatakan bahwa secara simultan lingkungan kerja berpengaruh terhadap pemilihan karir menjadi akuntan public pada mahasiswa akuntansi UNDIP dan UNIKA. Berdasarkan uraian diatas, dirumuskan hipotesis sebagai berikut :

H6 : Lingkungan kerja berpengaruh terhadap minat mahasiswa dalam pemilihan karir sebagai akuntan publik.

\section{Gambar 2. Model Empiris}

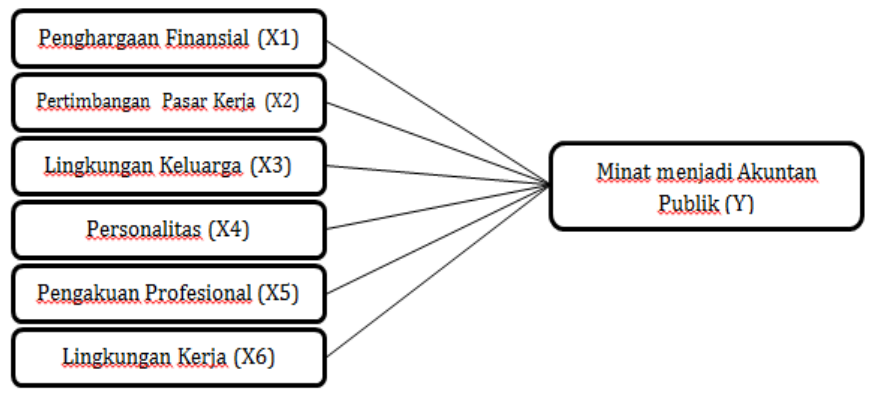

\section{METODE PENELITIAN}

Metode penelitian yang digunakan dalam penelitian ini adalah metode survei dengan penyebaran kuesioner sebagai alat untuk mendapatkan data. Populasi dalam penelitian ini adalah Mahasisa Program study Akuntansi di Universitas Serang Raya yang berlokasi di Provinsi Banten, Indonesia. Sampel yang digunakan dalam penelitian ini adalah 129 responden. Purposive sampling digunakan sebagai metode pengambilan sampel dalam penelitian ini untuk menarik responden dengan kriteria Mahasiswa pada tingkat semester 7 (tujuh). Data dikumpulkan dengan menyebarkan kuesioner melalui aplikasi google form kepada responden pada tahun 2017. Setiap pernyataan dari variable yang diteliti menggunakan skala likert (Sugiyono, 2000) dan masing-masing butir pernyataan diberi skor 1 sampai dengan 5. Metode 
analisis data dilakukan dengan menggunakan bantuan program spss (Statisticial Package For social Science). Alat analisis yang digunakan dalam penelitian ini yaitu analisis regensi berganda.

Indikator yang digunakan dalam penelitian ini untuk mengukur variabel Penghargaan Finansial (X1) diuji dengan tiga butir pernyataan seperti gaji awal yang tinggi (PF1) potensi kenaikan gaji (PF2) dan tersedianya dana pensiun (PF3) yang diadopsi dari Rahayu (2003). Pertimbangan pasar kerja (X2) menurut Rasmini (2007) keamanan kerja yang lebih terjamin (PPK1). Lingkungan Keluarga (X3) berasal dari Anis dan Lyna (2014) yaitu : perhatian orang tua (LKG1), dukungan orang tua (LKG2) dan Profesi yang ada di keluarga (LKG3). Personalitas (X4) menggunakan indikator : sesuai dengan kepribadian yang dimiliki (PS1), indepedensi dalam menjalakan profesi (PS2), dan kejujuran dalam menjalankan tugas (PS3), Wicaksono (2011). Pengakuan professional (X5) yang akan diuji dalam penelitian ini seperti kesempatan untuk berkembang (PFS1), kemungkinan bekerja dengan ahli lain (PFS2), adanya pengakuan atas prestasi (PFS3) Rahayu (2003). Variabel Lingkungan kerja (X6) diuji dengan lima indikator yang diadopsi dari Rahayu (2003) yaitu : Pekerjaan rutin (LK1), pekerjaan lebih cepat dapat diselesaikan (LK2), pekerjaan lebih atraktif (LK3), lingkungan pekerjaan yang menyenangkan (LK4), tingkat kompetisi antar karyawan lebih tinggi (LK5).

\section{HASIL DAN PEMBAHASAN}

\section{G. Analisis Deskriptif}

Hasil statistik deskriptif dari variabel Minat menjadi akuntan publik (Y), Penghargaan finansial (X1), Pertimbangan Pasar Kerja (X2), Lingkungan Keluarga (X3), Personalitas (X4) Pengakuan Profesional (X5) dan

Lingkungan Kerja (X6) seperti pada tabel berikut ini.

Tabel 1. Statistik Deskriptif

\begin{tabular}{cccc}
\hline Variable & Mean & Std. Deviation & N \\
\hline Minat Menjadi Akuntan Publik & 4.5926 & .54863 & 129 \\
Penghargaan Finansial & 4.5685 & .53749 & 129 \\
Pertimbangan Pasar Kerja & 4.8140 & .21613 & \\
Lingkungan Keluarga & 4.5607 & .53357 & 129 \\
Personalitas & 4.5762 & .51497 & 129 \\
Pengakuan Profesional & 4.5426 & .51886 & 129 \\
Lingkungan Kerja & 4.5767 & .53481 & 129 \\
\hline
\end{tabular}

Sumber : Data olahan, 2018

\section{H. Uji Reabilitas}

Uji ini dilakukan dengan cara membandingkan angka cronbach's alpha dengan kententuan cronbach's alpha adalah minimal 0,6. Artinya jika nilai cronbach's alpha didapatkan lebih besar dari 0.6 maka disimpulkan kuesioner tersebut reliabel. Hasil penenlitian menunjukan bahwa kuesioner penelitian untuk masing-masing indicator reliable yaitu seluruh variable independen dan variable dependen $>0,600$. 
Table 2. Reliability Statistics

Cronbach's

\begin{tabular}{rr} 
Alpha & N of Items \\
\hline .990 & 29 \\
\hline
\end{tabular}

Sumber : Data olahan, 2018

\section{Uji Multikolinieritas}

Disimpulkan bahwatidak terjadi multikolinieritas diantara variable-variabel independen pada persaman regresi. Suatu variable digolongkan memiliki kolinearitas tinggi apabila nilai VIP $<5$ atau memiliki nilai Tolerance yang mendekati nol.

Table 3. Uji Multikolinieritas

\begin{tabular}{cccl}
\hline \multirow{2}{*}{ Model } & \multicolumn{2}{c}{ Kollinearitas Statistik } & Hasil \\
& Tolerance & VIF & \\
\hline Penghargaan Finansial & .963 & 1.253 & Tidak Terjadi Multikolinieritas \\
Pertimbangan Pasar Kerja & .752 & 1.220 & Tidak Terjadi Multikolinieritas \\
Lingkungan Keluarga & .953 & 1.121 & Tidak Terjadi Multikolinieritas \\
Personalitas & .942 & 1.027 & Tidak Terjadi Multikolinieritas \\
Pengakuan Profesional & .940 & 1.070 & Tidak Terjadi Multikolinieritas \\
Lingkungan Kerja & .977 & 1.136 & Tidak Terjadi Multikolinieritas \\
\hline
\end{tabular}

Sumber : Data olahan, 2018

Table 4. Hasil Regensi Linear Berganda

\begin{tabular}{|c|c|c|c|c|c|}
\hline \multirow{2}{*}{ Model } & \multicolumn{2}{|c|}{$\begin{array}{l}\text { Unstandardized } \\
\text { Coefficients }\end{array}$} & \multirow{2}{*}{$\begin{array}{c}\text { Standardized } \\
\text { Coefficients } \\
\text { Beta } \\
\end{array}$} & \multirow{2}{*}{$\mathbf{t}$} & \multirow{2}{*}{ Sig. } \\
\hline & B & $\begin{array}{l}\text { Std. } \\
\text { Error }\end{array}$ & & & \\
\hline (Constant) & .123 & 0.25 & & 4.547 & .000 \\
\hline Penghargaan Finansial & .145 & 0.25 & 301 & 5.715 & .000 \\
\hline Pertimbangan Pasar Kerja & .146 & 0.28 & 285 & 5.255 & .000 \\
\hline Lingkungan Keluarga & .113 & .033 & 213 & 3.131 & .000 \\
\hline Personalitas & .143 & 0.27 & 285 & 5.367 & .000 \\
\hline Pengakuan Profesional & .438 & .320 & 258 & 4.928 & .000 \\
\hline Lingkungan Kerja & .143 & .027 & 282 & 5.169 & .000 \\
\hline
\end{tabular}

Sumber : Data olahan, 2018

\section{J. Pembahasan Hipotesis}

Hasil dari pengujian hipotesis 1 menunjukan bahwa variable Penghargaan Finansial berpengaruh positif dan signifikan terhadap minat mahasiswa menjadi akuntan public. Ini berarti $\mathrm{H} 1$ diterima. Hasil dari pengujian hipotesis yang menganalisis hubungan antara penghargaan finansial dan minat mahasiswa menjadi akuntan public memberikan nilai ststistik sebesar 5.715 dan lebih besar dari nilai yang dibutuhkan >1,96. Hal ini sejalan dengan penelitian yang dilakukan Putro (2012) yang menyatakan hal yang sama. Penghargaan finansial merupakan salah satu factor penting yang mempengaruhi minat mahasiswa akuntansi untuk berkarir sebagai akunatn public karena penghargaan finansial dipandang sebagai alat ukur untuk menilai pertimbangan jasa yang telah diberikan pegawai sebagai imbalan yang telah diperolehnya. Jika penghargaan finansial profesi akuntan public semakin besar maka minat 
mahasiswa untuk berkarir sebagai akuntan public juga akan semakin tinggi.

Pertimbangan pasar kerja berpengaruh positif dan signifikan terhadap minat mahasiswa berkarir menjadi akuntan public. Hal ini ditunjukan dengan hasil nilai statistic sebesar 5.255 yang lebih besar dari nilai t-tabel >1,96 yang artinya $\mathrm{H} 2$ diterima. Hasil penelitian ini konsisten dengan penelitian yang dilakukan oleh Alhadar (2013) yang menytakan bahwa Mahasiswa yang memilih karir sebagai akuntan publik, akuntan pendidik, akuntan perusahaan dan akuntan pemerintah sama-sama menganggap bahwa karir yang di pilih memberikan keamanan kerja yang lebih terjamin (tidak mudah di PHK) dan mudah untuk mengakses adanya lowongan kerja.

Salah satu factor yang menjadi pertimbangan mahasiswa akuntansi dalam memilih profesi yang akan digelutinya adalah tersedianya lapangan pekerjaan terkait persaingan pasar kerja yang semakin ketat, keamanan kerja yang lebih terjamin (tidak mudah di PHK), Fleksibilitas karir dan juga mendapatkan kesempatan promosi dalam suatu profesi, khususnya profesi akuntan publik.

Hasil dari pengujian hipotesis 3 menunjukan bahwa variable Lingkungan Keluarga berpengaruh positif dan signifikan terhadap minat mahasiswa menjadi akuntan publik. Ini berarti $\mathrm{H} 3$ diterima. Hasil dari pengujian hipotesis yang menganalisis hubungan antara lingkungan keluarga dan minat mahasiswa menjadi akuntan publi memberikan nilai ststistik sebesar 3.131 dan lebih besar dari nilai yang dibutuhkan $>1,96$. Hal ini sejalan dengan penelitian yang dilakukan Santoso (2014) yang menemukan bahwa lingkungan keluarga memiliki pengaruh signifikan positif terhadap minat menjadi akuntan publik pada mahasiswa akuntansi.

Pemilihan profesi yang akan digeluti oleh seseorang tidak terlepas dari peran suatu keluarga. Secara tidak langsung orang tua akan mengarahkan anaknya untuk kehidupan dimasa depan dan dapat mempengaruhi anaknya dalam memilih suatu profesi atau suatu pekerjaan. Pekerjaan dilingkungan keluarga juga menjadi factor timbulnya minat untuk menjadi akuntan public, misalnya keluarga yang berprofesi menjadi akuntan public membuat anggota keluarga yang lainnya memilih profesi yang sama. Menjadi akuntan public juga tidak terlepas dari perhatian dan dukukang dari lingkungan keluarga. Dengan demikian perhatian, dukungan, dan profesi yang ada pada keluarga akan berpengaruh terhadap minat mahasiswa akuntansi untuk berkarir menjadi akuntan public.

Personalitas berpengaruh positif dan signifikan terhadap minat mahasiswa berkarir menjadi akuntan public. Hal ini ditunjukan dengan hasil nilai statistic sebesar 5.367 yang lebih besar dari nilai t-tabel sebesar $>1.96$ yang artinya $\mathrm{H} 2$ diterima. Hasil penelitian ini konsisten dengan penelitian yang dilakukan oleh Dianati (2017) yang menyatakan bahwa personalitas semakin sesuai dengan kepribadian seseorang dengan pekerjaan menjadi akuntan publik maka minat mahasiswa dalam pemilihan karir sebagai akuntan publik menjadi tinggi.

Personalitas merupakan karakteristik psikologi dari dalam diri seseorang yang menentukan dan merefleksikan bagaimana seseorang tersebut merespon dan berperilaku didalam lingkungannya. Personalitas berpengaruh terhadap perilaku seseorang dalam mengendaliakan atau mencerminkan bagaimana seseorang bekerja. Salah satu factor seseorang meninggalkan atau kehilangan pekerjaannya karena tidak sesuai dengan kepribadian yang mereka miliki dengan bidang pekerjaannya.

Hasil dari pengujian hipotesis 5 menunjukan bahwa variable Pengakuan Profesional berpengaruh positif dan signifikan terhadap minat mahasiswa menjadi akuntan publik. Ini berarti H5 diterima. Hasil dari pengujian hipotesis yang menganalisis hubungan antara pengakuan profesional dan minat mahasiswa menjadi akuntan publik memberikan nilai ststistik sebesar 4.928 dan lebih besar dari nilai yang dibutuhkan >1,96. Hal ini sejalan dengan 
penelitian yang dilakukan Rahayu, dkk (2003) yang mengungkapkan bahwa mahasiswa yang memilih profesi akuntan public dan akuntan perusahaan menganggap bahwa preofesi yang mereka pilih akan memberikan banyak kesempatan untuk berkembang.

Mencari suatu pekerjaan atau memilih suatu profesi bukan hanya bertujuan untuk mencari penghargaan finansial tetapi juga ada keinginan untuk pengakuan berprestasi, dan kesempatan untuk berkembang. Mahasiswa akuntansi yang memiliki minat untuk menjadi akuntan public menganggap bahwa profesi yang mereka pilih akan memberikan kesempatan kepada mereka untuk mengembangkan dirinya dan adanya pengakuan akan profesionalismenya.

Lingkungan kerja berpengaruh positif dan signifikan terhadap minat mahasiswa berkarir menjadi akuntan public. Hal ini ditunjukan dengan hasil nilai statistic sebesar 5.169 yang lebih besar dari nilai t-tabel yang artinya $\mathrm{H} 2$ diterima. Hasil penelitian ini konsisten dengan penelitian yang dilakukan oleh Chan (20212) yang menyatakan bahwa lingkungan kerja memiliki pengaruh terhadap minat mahasiswa akuntansi untuk menjadi akuntan publik.

Lingkungan kerja merupakan segala sesuatu yang ada disekitar pekerja yang diharapkan dapat mempengaruhi dirinya dalam menjalankan tugas-tugas yang diembannya dengan situasi yang nyaman. Mahasiswa akuntansi yang memiliki minat berkarir sebagai akuntan public, menganggap lingkungan kerja sebagai akuntan public memiliki lingkungan kerja yang menyenangkan, karir yang dipilihnya memilki pekerjaan yang rutin dan cepat terselesaikan.

\section{SIMPULAN}

Berdasarkan hasil pembahasan dapat disimpulkan bahwa 6 hipotesis yang diukur dalam penelitian ini memberikan pengaruh positif dan signifikan. Penghargaan finansial mempengaruhi minat mahasiswa dalam pemilihan karir sebagai akuntan public, yang artinya semakin tinggi penghargaan finansial yang diberikan maka akan semakin tinggi pula minat mahasiswa berkarir sebagai akuntan public. Perkembangan pasar kerja. Pertimbangan pasar kerja berpengaruh terhadap minat mahasiswa dalam pemilihan karir sebagai akuntan public. Semakin besar pasar kerja yang tersedia maka semakin tinggi pula minat mahasiswa berkarir sebagai akuntan public. Lingkumgan keluarga mempengaruhi minat mahasisawa dalam pemilihan karir sebagai akuntan public. Semakin besar pengaruh keluarga dan orang tua yang diberikan maka akan mempengaruhi minat mahasiswa memilih karir sebgai akuntan public. Personalitas berpengaruh positif dan signifikan terhadap minat mahasiswa berkarir menjadi akuntan public. Semakin sesuai Kepribadian seseorang dengan pekerjaan menjadi akuntan public maka minat mahasiswa dalam pemilihan karir sebagai akuntan publik menjadi tinggi. Pengakuan profesional berpengaruh positif dan signifikan terhadap minat mahasiswa menjadi akuntan public. Mahasiswa akuntansi yang memiliki minat untuk menjadi akuntan public menganggap bahwa profesi yang mereka pilih akan memberikan kesempatan kepada mereka untuk mengembangkan dirinya dan adanya pengakuan akan profesionalismenya. Lingkungan kerja berpengaruh positif dan signifikan terhadap minat mahasiswa berkarir menjadi akuntan public. Mahasiswa akuntansi yang memiliki minat berkarir sebagai akuntan public, menganggap lingkungan kerja sebagai akuntan public memiliki lingkungan kerja yang menyenangkan, karir yang dipilihnya memilki pekerjaan yang rutin dan cepat terselesaikan. 


\section{DAFTAR PUSTAKA}

Aldahar, Mochamad Audi. 2013. "Faktor-Faktor Yang Mempengaruhi Pemilihan Karir Sebagai Akuntan Publik (Studi Empiris pada Mahasiswa Akuntansi dan PPAK Universitas Hasanudin). Skripsi. Fakultas Ekonomi dan Bisnis Universitas Hasanudin, Makassar.

Andersen, William. 2012. "Analisis Persepsi Mahasiswa Akuntansi Dalam Pemilihan Profesi Sebagai Akuntan (studi empiris Pada Mahasiswa Akuntansi UNDIP, UNIKA, UNNES, UNISSULA, UDNIUS, UNISBANK, STIE Total Win dan Mahasiswa PPA UNDIP). Skripsi. Universitas Diponogoro

Apriliyan, L.A. 2011. Faktor-Faktor Yang Mempengaruhi Mahasiswa Akuntansi Dalam Pemilihan Karir Menjadi Akuntan Publik, Skripsi, Fakultas Ekonomi dan Bisnis Universitas Diponogoro.

Chan, Andi Setiawan. 2012. "Analisis Faktor Yang Mempengaruhi Pemilihan Karir Menjadi Akuntan Publik Oleh Mahasiswa Jurusan Akuntansi. Jurnal Ilmiah Mahasiswa Akuntansi. $1(1), 53-58$

Dalyono. 2005. "Psikologi Pendidikan”. Jakarta. PT. Rineka Cipta

Dianati, Nur Amalia. 2017. "Faktor-Faktor Yang Mempengaruhi Minat Mahasiswa Akuntansi STIE Perbanas Surabaya Dalam Pemilihan Karir Sebagai Akuntan Publik. Artikel Ilmiah. Sekolah Tinggi Ilmu Ekonomi Perbanas Surabaya.

Fifi Chairunnisa. 2014. "Analisis Faktor-Faktor Yang Mempengaruhi Minat Mahasiswa Akuntansi Untuk Berkarir Sebagai Akuntan Publik". Jurnal Audit dan Akuntansi Fakultas Ekonomi Universitas Tanjungpura, Vol 3. No. 2. Desember 2014. Hal. 1-26.

Harianti, Siska Sarli. 2017. "Pengaruh Penghargaan Finansial, Pertimbangan Pasar Kerja dan Lingkungan Keluarga Terhadap Minat Menjadi Akuntan Publik (Studi Empiris MahasiswaS1 Akuntansi Universitas Negeri dan Swasta Kota Padang)". Artikel.

Merdekawati. 2011. "Faktor-Faktor Yang Mempengaruhi Pemilihan Karir Akuntan Publik dan Non Akuntan Publik". Jurnal Akuntansi dan Investasi. Vol. 13. No. 1. 2011. Hal 219-242

Putro, A.S. 2012. "Analisis Faktor-Faktor Yang Mempengaruhi Minat Mahasiswa Akuntansi Untuk Berkarir Menjadi Akuntan Publik. Skripsi. Universitas Negeri Yogyakarta.

Rahayu, s, Dkk. 2003. "Persepsi Mahasiswa Akuntansi Mengenai Faktor-Faktor Yang Mempengaruhi Pemilihan Karir. Simposium Nasional Akuntansi VI.

Rivai, Veithzal dan ElaJaufani Sagala. 2013. "Manajemen Sumber Daya Manusia Untuk Perusahaan : Dari Teori Ke Praktik“. Edisi Kedua. Jakarta. PT. Raja Grafindo Persada.

Santoso, Cahyo Budi. 2014. "Pengaruh Lingkungan Keluarga, Motivasi Dan Persepsi Mahasiswa Tentang Profesi Akuntan Publik Terhadap Minat Menjadi Akuntan Publik". Jurnal Measurement, Vol 8 No. 1 Maret 2014. 
Sartika, Meli. 2014. Faktor-Faktor Yang Mempengaruhi Minat pemilihan Karir Sebagai Akuntan Publik dan Non Akuntan Publik (Studi Pada Mahasiswa Jurusan Akuntansi Universitas Bengkulu). Skripsi. Fakultas Ekonomi dan Bisnis Jurusan Akuntansi Universitas Bengkulu.

Suyono, Nanang Agus. 2014. Analisis Faktor-Faktor yang Mempengaruhi Pemilihan Karir Sebagai Akuntan Publik. Jurnal PPKM II. 69-83

Undang-Undang Republik Indonesia Nomor 5 tentang Akuntan Publik (2011). (http://www.djpp.depkumhm.go.id/inst/2011/05.pdf. Diunduh pada Desember 2018

Wicaksono, E. 2011. "Persepsi Mahasiswa Akuntansi Mengenai Faktor-Faktor Yang Membedakan Pemilihan Karir Profesi Akuntan. Skripsi. Semarang. Program Sarjana Fakultas Ekonomi Universitas diponogoro.

Widyanti, Rina dan Dedi Saputra. 2018. "Pengaruh Penghargaan Finansial, Pertimbangan Pasar Kerja, dan Lingkungan KeluargaTerhadap Minat Menjadi Akuntan Publik (Studi Empiris Mahasiswa S1 Akuntansi Universitas Ekasakti). Universitas Muhamadiyah Sumatera Barat. 